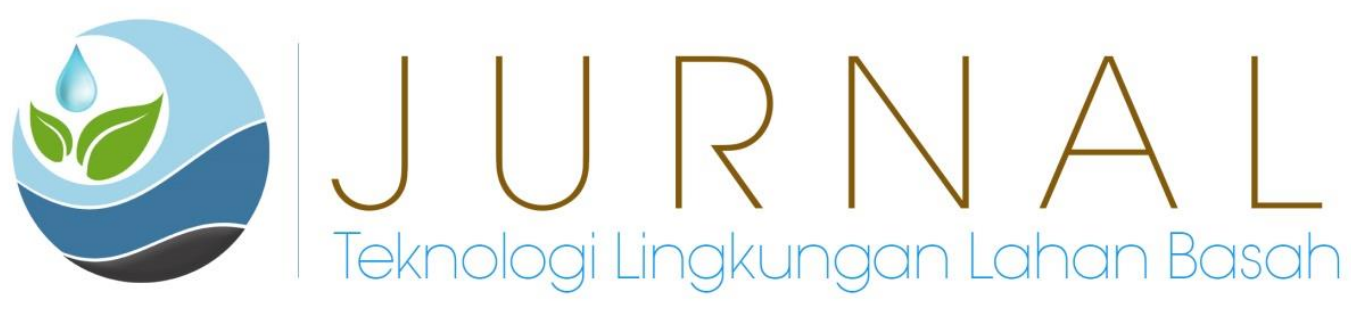

\title{
Karakteristik Pengunjung Ekowisata Pesisir Pantai Arung Buaya Desa Meliah Kecamatan Subi Kabupaten Natuna
}

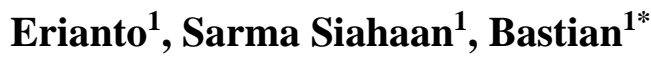 \\ ${ }^{1}$ Jurusan Kehutanan Universitas Tanjungpura \\ E-mail: bastianahon@gmail.com
}

\begin{abstract}
This study examines the characteristics of visitors on the coast of Arung Buaya, Meliah Village, Subi District, Natuna Regency, Riau Islands Province. This tourism object is quite promising but it is not well known and managed by the society well, even though it has the potential to be developed through ecotourism conservation and become a source of regional income. The purpose of this study was to determine the characteristics of coastal ecotourism visitors to the Arung Buaya coast. This type of research is a descriptive survey. The sampling technique used accidental sampling by directly interviewing visitors who were met when collecting data. At the time of the interview, a questionnaire was used as a guide for questions on collected variables including visitor characteristics based on gender, age, occupation and area of origin. The results of the study found that the most visitors were female, aged 17-25 years and were dominated by students. Based on the origin, most of the visitors come from Meliah Village, which is about $3.3 \mathrm{~km}$ away and takes about 15-20 minutes. The conclusion from this research is that the tourism object on the coast of Arung Beach, Meliah Village has the potential to be developed with a panorama that is owned so that it can be a source of community income. It is recommended that this tourist attraction be developed with a more professional management and complete arenas tourism for all age groups, especially those aged 17-25 years.
\end{abstract}

Keywords: Characteristics of visitors, Arung Buaya of Beach, subi Island.

\begin{abstract}
Abstrak
Penelitian ini mengkaji tentang karakteristik pengunjung di pesisir pantai Arung Buaya Desa Meliah Kecamatan Subi, Kabupaten Natuna Provinsi Kepulauan Riau. Objek wisata ini cukup menjanjikan namun belum dikenal dan dikelola masyarakat dengan baik, padahal memiliki potensi untuk dapat dikembangkan melalui konservasi ekowisata dan menjadi sumber pendapatan daerah. Tujuan dari penelitian ini adalah untuk mengetahui karakteristik pengunjung ekowisata pesisir pantai Arung Buaya. Jenis penelitian adalah survey deskriptif. Teknik penentuan sampel menggunakan accidental sampling dengan mewawancarai langsung pengunjung yang ditemui saat pengambilan data. Wawancara dilakukan dengan menggunakan kuisioner sebagai panduan pertanyaan terhadap variabel yang dikumpulkan meliputi karakteristik pengunjung berdasarkan jenis kelamin, usia, pekerjaan dan daerah asal. Hasil penelitian menemukan bahwa pengunjung yang paling banyak berjenis kelamin perempuan dengan kisaran umur 17-25 tahun dan didominasi oleh pelajar atau mahasiswa. Berdasarkan asal pengunjung sebagian besar berasal dari Desa Meliah yang jaraknya kurang lebih 3,3 km dengan waktu tempuh lebih kurang 15-20 menit. Dari penelitian ini, diketahui bahwa objek wisata di Pesisir Pantai Arung Desa Meliah memiliki potensi untuk dikembangkan. Dengan panorama yang dimiliki, bisa menjadi sumber pendapatan masyarakat. Objek wisata ini perlu dikembangkan dengan mengacu karakteristik pengunjung ekowisata ini.
\end{abstract}

Kata Kunci: Karakteristik pengunjung, Pantai Arung Buaya, Pulau Subi. 


\section{PENDAHULUAN}

Indonesia memiliki destinasi wisata yang beragam di setiap daerah baik dari wisata darat, laut, alam maupun wisata budaya atau religi yang menghasilkan keindahan dan keanekaragam destinasi yang menarik untuk dikunjungi (Probowati, $d k k$ 2015). Wisata pantai sebagai salah satu bentuk kegiatan yang memanfaatkan sumberdaya yang ada di pantai (Putra dkk, 2013). Wilayah pesisir memiliki potensi, keunikan dan keindahan alam sebagai daya tarik wisata. Kawasan ekowisata pesisir Pantai Arung Buaya memiliki sumber daya alam flora dan fauna, dengan keindahan dan kenyamanan dengan adanya pohon-pohon yang beraneka ragam dan rindang. Di sekitar pantai ditemukan pohon kelapa (cocos nucifera), cengkeh (Syigium aromaticum), pandan laut (Pandanus odorifer), dan beberapa pohon besar dimanfaatkan wisatawan untuk istirahat dan berteduh. Semenanjung kiri dan kanan pesisir pantai Arung Buaya terdapat jenis pasir berlumpur, yang ditumbuhi pohon mangrove (Rhizophora) yang bervariasi dan menambah keindahan pesisir pantai Arung Buaya. Jarak ke hutan mangrove dapat ditempuh pengunjung dengan berjalan kaki sejauh 60-70 meter ke titik pusat lokasi wisata pantai Arung Buaya. Kondisi fisik sebagai perpaduan pasir dan bebatuan besar, dimanfaatkan wisatawan untuk berbagai kegiatan, seperti berjemur, menikmati pemandangan, memancing, dan kegiatan lainnya. Sehingga aktivitas pariwisata pun dapat dikembangkan dan menghasilkan dampak positif dengan ikut meningkatkan perekonomian masyarakat (Wakhidah, Dewi, \& Ristianti, 2013).

Kabupaten Natuna memiliki daerah pesisir yang sangat indah dan terdapat beberapa keunikan di dalamnya baik dari segi ekosistem darat maupun ekosistem laut, pantai Arung Buaya merupakan salah satu pantai yang berada di Kabupaten Natuna. Pantai Arung Buaya ini berada di Desa Meliah Kecamatan Subi Kabupaten Natuna dengan memiliki kawasan pesisir yang cukup bagus untuk dikembangkan sebagai objek wisata baru. Pantai ini sangat menarik dan cukup digemari oleh masyarakat setempat. Namun pengembangan wisatanya masih minim dan jumlah pengunjung masih terbatas karena belum dikelola dengan baik. Padahal objek wisata ini dapat dikembangkan dan dapat memberikan dampak positif serta meningkatkan kesejahetraan masyarakat setempat. Dari penelitian Bastian pada tahun 2020, diketahui bahwa dari hasil penilaian objek dan daya tarik ekowisata pesisir pantai Arung Buaya Desa Meliah Kecamatan Subi Kabupaten Natuna dikategorikan A (baik) dengan nilai 887,7 artinya potensial untuk dikembangkan sesuai dengan panduan Direktur Jenderal Perlindungan Hutan dan Konservasi Alam (ODTWA PHKA) tahun 2003. Tujuan dari penelitian ini adalah untuk mengetahui karakteristik pengunjung sebagai masukan dalam pengembangan objek ekowisata yang berkelanjutan dan professional.

\section{METODE PENELITIAN}

Jenis penelitian adalah survey deskriptif berlokasi di kawasan ekowisata Pesisir Pantai Arung Buaya. Waktu penelitian adalah 1 bulan (1 Februari - 2 Maret 2020). Objek penelitian adalah kawasan ekowisata Pantai Arung Buaya di Desa Meliah Kecamatan Subi Kabupaten Natuna (3.1488036363586556, 108.84213374238553).

Populasi dalam penelitian ini adalah pengguna ekowisata (pengunjung) Pantai Arung Buaya di Desa Meliah Kecamatan Subi Kabupaten Natuna. Jumlah populasi diperoleh dari pengelola bahwa rata-rata jumlah pengunjung dalam satu minggu sebanyak 25 orang atau mencapai 100 orang setiap bulannya dan teramai pada hari Sabtu dan Minggu. Berdasarkan data tersebut maka jumlah responden yang diambil sebanyak 100 
orang pengunjung sebagai responden. Metode pemilihan responden secara accidental dengan mewawancarai tentang karakteristik seperti umur, pekerjaan, asal pengunjung, jenis kelamin. Tujuan wawancara untuk memberikan gambaran mengenai wisatawan yang sering berkunjung dan memanfaatkan pantai Arung Buaya sebagai tempat rekreasi. Kriteria responden adalah sehat jasmani, bersedia berpartisipasi dalam penelitian, dapat berkomunikasi dengan baik, sehat jasmani dan rohani serta berumur $\geq 17$ tahun. Analisis data dalam penelitian ini menggunakan analisis deskriptif kuantitatif yaitu menjelaskan semua angka yang diperoleh dari setiap nilai karakteristik

\section{HASIL DAN PEMBAHASAN Karakteristik Pengunjung Ekowisata Pesisir Pantai Arung Buaya}

Berdasarkan hasil data responden didapat data karakteristik pengunjung yang disajikan dalam diagram berikut ini.

\section{a. Sebaran Wisatawan Berdasarkan Alamat Asal}

Pengunjung yang paling mendominasi pada wilayah kecamatan ialah pengunjung yang berasal dari desa Meliah yaitu dengan persentase sebesar 39\% karena jarak desa Meliah ke lokasi wisata tidak begitu jauh sehingga waktu dan biaya yang dikeluarkan tidak besar/terjangkau. Semakin dekat jarak yang ditempuh pengunjung menuju lokasi wisata, maka semakin kecil biaya perjalanan yang di keluarkan (Sihotang dkk, 2014).

Pengunjung yang berkunjung masih didominasi masyarakat sekitar yang lebih mengetahui keberadaan pantai Arung Buaya ini. Data persebaran wisatawan berdasarkan alamat pengunjung dapat dilihat pada Gambar 1.

\section{Asal Pengunjung}

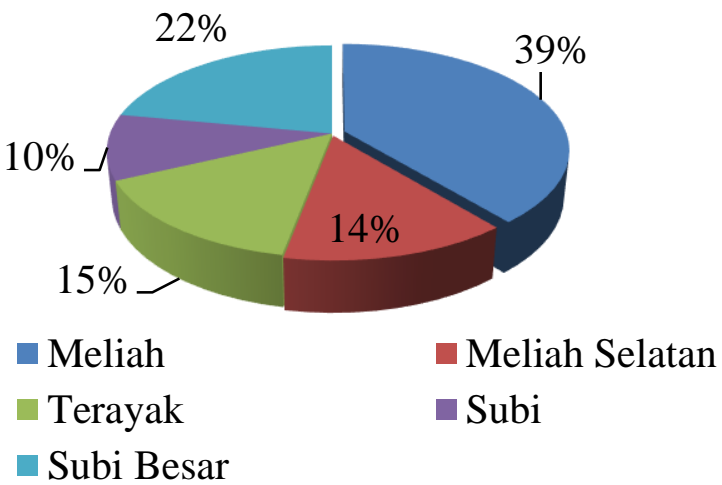

\section{Gambar 1. Sebaran Wisatawan Berdasarkan Asal Pengunjung}

b. Sebaran Wisatawan Berdasarkan Jenis Kelamin

Perbedaan jenis kelamin dapat menyebabkan adanya perbedaan dalam menentukan suatu persepsi terhadap objek tertentu, karena penilaian dari pria dan wanita cenderung memiliki sudut pandang yang berbeda dalam menilai suatu hal (Savira, 2012). Banyak nya jumlah pengunjung antara laki-laki dan perempuan diperoleh secara ketidaksengajaan, dengan menggunakan metode accidental sampling. Komposisi pengunjung kawasan ekowisata pesisir pantai Arung Buaya berdasarkan jenis kelamin yang paling mendominasi ialah pengunjung berjenis kelamin perempuan dengan persentase sebesar 54\% dibandingkan dengan pengunjung laki-laki $46 \%$. Berdasarkan data ini dapat diperoleh gambaran antara perempuan dan laki-laki memiliki perbedaan dalam kebutuhan rekreasi, dapat dilihat pada Gambar 2. 


\section{Jenis kelamin}

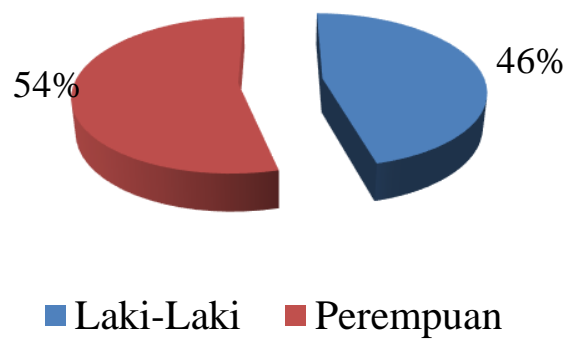

Gambar 2. Sebaran Wisatawan Berdasarkan Jenis Kelamin.

c. Sebaran Wisatawan Berdasarkan Pekerjaan

Wisatawan pada ekowisata pesisir pantai Arung Buaya mempunyai latar belakang pekerjaan ataupun profesi yang beragam. Berdasarkan data yang terkumpul diketahui bahwa pengunjung sebagai pelajar atau mahasiswa (46\%), yang bekerja sebagai nelayan (14\%), ibu rumah tangga (13\%), PNS (9\%), honorer (13\%) dan wirausaha (5\%). Data kuesioner yang diperoleh dari lapangan, pengunjung yang mendominasi adalah pelajar/mahasiswa dengan persentase $46 \%$, hal ini dikarenakan pelajar/mahasiswa memiliki rasa ingin tahu cukup tinggi serta memiliki waktu luang lebih banyak. Waktu luang berpengaruh terhadap keputusan pengunjung untuk memilih tempat wisata berdasarkan waktu luang yang dimiliki (Sihotang dkk, 2014). Gambaran diagram berdasarkan pekerjaan wisatawan pantai Arung Buaya dapat dilihat pada Gambar 3.

Pekerjaan Pengunjung

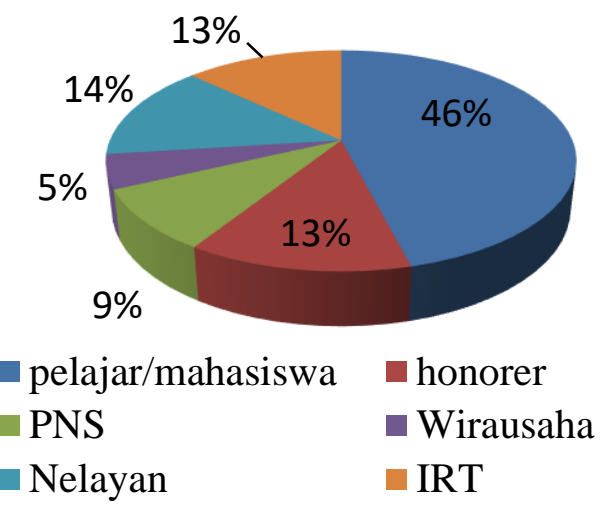

Gambar 3. Sebaran Wisatawan Berdasarkan Pekerjaan

d. Sebaran Wisata Berdasarkan Umur

Berdasarkan data responden yang terkumpul rata-rata pengunjung yang datang ke kawasan pantai pantai Arung Buaya terbagi ke dalam beberapa golongan umur, diperoleh bahwa pengunjung yang berusia 17-25 tahun 59\%, berusia 26-50 tahun 38\% dan yang berumur $>50$ tahun $3 \%$. Usia berkorelasi dengan permintaan rekreasi, semakin meningkat usia seseorang maka akan semakin bertambah pula kendala yang akan dihadapi dalam melakukan kegiatan rekreasi (Rahmawaty, $d k k$ 2006). Berdasarkan data responden usia yang paling sering berkunjung adalah usia rentang 17-25 tahun. Ada yang datang ke tempat wisata hanya datang untuk bermain, berkreasi, berfoto-foto, namun ada sebagian juga dari mereka yang datang menjadikan pantai sebagai objek untuk memancing, dan menghilang penat ketika lelah bekerja. Gambaran diagram umur wisatawan tersebut dapat dilihat pada Gambar 4. 


\section{Umur Responden}

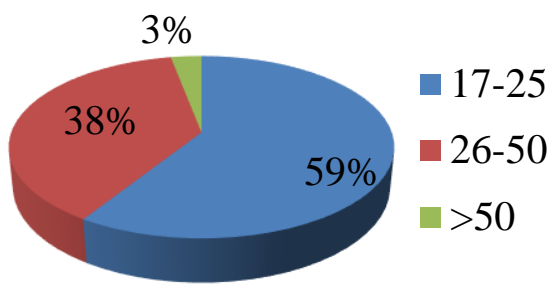

Gambar 4. Sebaran Wisatawan Berdasarkan Umur

Objek wisata di Pesisir Pantai Arung Desa Meliah memiliki potensi untuk dikembangkan. Dengan panorama yang dimiliki, dapat menjadi sumber pendapatan masyarakat. Dalam pengembangan objek wisata ini, bisa mengacu pada karakteristik pengunjung pantai ini.

\section{PENUTUP}

\section{Kesimpulan}

Karakteristik pengunjung Kawasan ekowisata pesisir pantai Arung Buaya didominasi oleh wisatawan berumur 17-25 tahun, jenis kelamin didominasi perempuan, pekerjaan sebagai pelajar atau mahasiswa, dan beberapa dari mereka ada yang sudah bekerja, pengunjung berasal dari Desa Meliah.

\section{Saran}

1. Instansi terkait dan pengelola wisata harus bekerjasama dalam pengembangan kawasan ekowisata pesisir Pantai Arung Buaya. Hal ini bisa disesuaikan dengan karakteristik pengunjung sehingga bisa lebih kreatif dan inovatif

2. Sarana dan prasarana perlu ditingkatkan sehingga bisa menambah jumlah pengunjung ekowisata tersebut.

\section{UCAPAN TERIMA KASIH}

Terima kasih kepada Fakultas kehutanan Universitas Tanjungpura Pontianak, serta semua pihak yang terlibat dan membantu proses pengerjaan penelitian ini.

\section{DAFTAR PUSTAKA}

Bastian. 2020. Penilaian Daya Tarik Objek Wisata Pesisir Pantai Arung Buaya Desa Meliah Kecamatan Subi Kabupaten Natuna. Universitas Tanjungpura.

Perlindungan Hutan Dan Konservasi Alam (PHKA 2003). Pedoman Analisis Daerah Operasi Objek Dan Daya Tarik Wisata Alam (ADO-ODTWA). Direktorat Jendral Perlindungan Hutan Dan Konservasi Alam. Bogor.

Probowati AN, Anifatul H \& Fajar W. (2015). Identifikasi Faktor Penentu Pengembangan Obyek Wisata Di Kabupaten Demak. Jurnal Ekonomi Pembangunan, 1 (1): $1-8$.

Putra, A.H.F., Fachrudin, A., Niken, T.M.P., Setyo, B.S., 2013. Kajian Keberlanjutan Pengelolaan Wisata Pantai di Pantai Pasir Putih Bira, Bulukumba, Sulawesi Selatan. Jurnal Penelitian dan Pengembangan Kepariwisataan Indonesia. 8 (3): 241-254. 
Rahmawaty, Pian ZA, Daulay DNO. 2006. Karakteristik Pengunjung Rekreasi dan Objek Wisata di Taman Hutan Raya DR. Moh. Hatta. Universitas Sumatra Utara Repository. Medan. Sumatra Utara.

Savira M., 2012. Pengaruh Perbedaan Jenis Kelamin Terhadap Prilaku Pembelian Produk Ramah Lingkungan di Jakarta.Tesis Program Studi Magister Manajeman Universitas Indonesia, Jakarta.

Sihotang, J.J., C. Wulandari., S. Herwanti. 2014. Nilai Objek Wisata Air Terjun Way Lalaan Provinsi Lampung dengan Metode Biaya Perjalanan (Travel Cost Method). Jurnal sylva lestari. 2(3):11-18

Undang-undang No 23Tahun 2003 Pasal 7 Tentang Pemilihan Umum Presiden dan Wakil Presiden.

Wakhidah K, Dewi S, Ristianti N (2013). Bentuk Pengembangan Pariwisata Pesisir Berkelanjutan di Kabupaten Pekalongan. Ruang: Jurnal Perencanaan Wilayah dan Kota. 1(2), 261-270. 